\title{
Topical collection editor's note: Innovations in teaching and industry practices
}

Yoon-Jung Lee*

\author{
${ }^{*}$ Correspondence: \\ yleehe@korea.ac.kr \\ Korea University, Seoul, \\ Republic of Korea
}

The topical collection of Fashion and Textiles is a result of 2014 KSCT-ITAA Joint Symposium which took place at the ITAA Annual Conference in Charlotte, North Carolina, USA. The theme of the joint symposium was The Culture of Collaborations: New Directions in Clothing and Textiles Teaching and Research, and over fifty papers were presented at the conference. Session 1 included presentations on Curriculum, Undergraduate Programs, and Industry Relations, and Session 2 included research presentations on Innovative Research/Creative Activity in Clothing and Textiles. Authors of the presented papers were invited to submit their manuscripts to the Topical Collection of Fashion and Textiles. One out of the four articles in this collection (Ha-Brookshire), was originally presented in Session 1 and the other three were presented in Session 2: one in the field of consumer behavior (Yun, Jung, and Choo) and two in the field of product development (Kim; Sang and Park). The articles suggest directions for innovations in teaching and practices, thus the topical collection was titled Innovations in Teaching and Industry Practices.

Ha-Brookshire's article, “Global Sourcing: New Research and Education Agendas for Apparel Design and Merchandising" is a concept paper that proposes new research and educational agendas. The author reviews the role of global sourcing in the industry and education, and explores the relationship between apparel design or apparel merchandising and global sourcing. The author asserts that global sourcing may serve as a connector that links between the conventionally divided two major tracks in apparel industry: apparel design and apparel merchandising.

The research article by Yun, Jung, and Choo explores shopper experience in fitting rooms in the specialty retailers of private label apparel (SPA) stores using grounded theory method. They focused on the fact that the fitting rooms of SPA stores, which is a relatively new type of retailer, provide shoppers unobstructed opportunities in that these stores usually provide larger number of fitting rooms which are less controlled compared to conventional apparel stores. The article describes the activities that shoppers perform in the fitting rooms in detail, as well as the contextual and intervening conditions of such activities. According to the authors, in the fitting rooms in SPA stores, shoppers engage in activities beyond just checking out the fit of the selected garments. The fitting rooms liberate shoppers to experiment with the abundant products, enjoying different images the garments allow them to create, and also obtain fashion information from observing other shoppers in line.

\section{Springer}

(c) 2015 Lee. This article is distributed under the terms of the Creative Commons Attribution 4.0 International License (http://creativecommons.org/licenses/by/4.0/), which permits unrestricted use, distribution, and reproduction in any medium, provided you give appropriate credit to the original author(s) and the source, provide a link to the Creative Commons license, and indicate if changes were made. 
Kim's research on "Pants Lining Manufacturing Survey of Menswear Brands in Korea" reports a survey results of thirteen Korean menswear brands regarding how the manufacturers develop pants lining. The patternmaking of pants lining is a relatively neglected area of research considering its importance for fit and comfort. The author examined the industrial practices of pants lining manufacturing, as a foundational research to pants lining patternmaking.

Sang and Park examined the structural effect of high stretch knitted fabric on its appearance, stretch property, and clothing pressure. Authors analyzed fabric size (weight and thickness), stretch properties (stretch, elastic recovery), and clothing pressure of various knit structures for the purpose of examining the properties of high stretch knitted fabric. By examining the properties of high stretch fabric, which is often used as a material for the compression garments, this study facilitates an effective design and development of stretch compression products such as functional and medical compression garments.

These articles presented in this topical collection suggest directions for innovations in clothing and textiles industries and academia. It is expected that these articles generate further interests and discussions and facilitate innovative teaching and industry practices.

Received: 18 September 2015 Accepted: 18 September 2015

Published online: 27 November 2015

Submit your manuscript to a SpringerOpen ${ }^{\circ}$ journal and benefit from:

- Convenient online submission

- Rigorous peer review

- Immediate publication on acceptance

- Open access: articles freely available online

- High visibility within the field

- Retaining the copyright to your article

Submit your next manuscript at $\boldsymbol{s p r i n g e r o p e n . c o m ~}$ 